\title{
ANALYSIS OF DIFFERENT PREVENTIVE MEASURES TO IMPROVE HOME OFFICE ERGONOMICS - RESULTS FROM A STUDY ON THE FIRST WAVE OF THE COVID-19 PANDEMIC IN LATVIA
}

\author{
Linda Matisāne ${ }^{1}$, Linda Paegle ${ }^{2}$, Ivars Vanadziṇš ${ }^{3}$, Asnate Anna Linde ${ }^{4}$, \\ Sarmīte Rozentāle ${ }^{5}$, Ieva Grīntāle ${ }^{6}$, Iveta Mietule ${ }^{7}$, Jeḷena Lonska ${ }^{8}$, \\ Lienīte Litavniece ${ }^{9}$, Iluta Arbidāne ${ }^{10}$
}

\begin{abstract}
:
Introduction: Telework, also known as remote work, distance work, telecommuting, was gaining popularity already before the COVID-19 pandemic. Despite benefits, telework can also cause workers' mental and physical health, and forced telework during the COVID-19 pandemic has promoted the onset of these problems.

Objectives: The objective of the study was to analyze the management of ergonomics in teleworking workplaces and the association between pain longer than three days and preventive measures provided by employers in Latvia during the $1 \mathrm{st}$ emergency restrictions, which were in force between 12 March and 9 June 2020 due to the COVID-19 pandemic.

Methods: Web-survey was used to gather information from respondents - workers. In total, 1006 workers fully filled in the questionnaire in October 2020. Four hundred eighty-three teleworkers of both genders were identified.

Results: $35.7 \%$ of respondents reported pain longer than three days. The odds of pain were increased in case of lack of all analyzed preventive measures. For those who reported not being provided with a computer and other IT equipment OR for pain was 1.50 (CI 0.95-2.37). Even higher OR was observed in case of not receiving advice on how to arrange an ergonomic workstation $(\mathrm{OR}=2.37$, CI 1.32-4.25) and not having identified working conditions ( $\mathrm{OR}=2.61, \mathrm{CI} 1.43-4.77)$. The highest risk was observed if the employer had not provided an office table and office chair (OR=5.46, CI 1.78-16.80).

Conclusion: Teleworkers not receiving support from the employer on the arrangement of home offices have an increased risk of having pain for longer than three days. Provision of an office worktable, an office chair, advice on how to arrange an ergonomic workplace and provision of workplace risk assessment are key measures to be taken by the employer to improve home office ergonomics of their workers.
\end{abstract}

JEL Classification Numbers: J81, DOI: https://doi.org/10.12955/pmp.v2.181

Keywords: telework, distance work, working at home, COVID-19, musculoskeletal pain, ergonomics

\section{Introduction}

Telework, also known as remote work, distance work, telecommuting, was gaining popularity already before the COVID-19 pandemic, which has been triggered by globalization, related competitive pressure in combination with technical improvements in information and communication technology (de Macêdo et al., 2020; Steidelmüller et al., 2020). Responding to the COVID-19 pandemic, governments have taken different measures to reduce the spreading of the virus, including workplace closures and requests to stay-at-home. As a result, a huge number of workers in many countries had to start teleworking without their approval and choice, but they were forced to do it either by the decision of the government or the employer (Oakman et al., 2020). Recent publications have already identified a need for future research to explore the impact of teleworking in such areas of life as health (e.g., musculoskeletal pain) and to provide evidence to develop policies and guidelines for working at home (de Macêdo et al., 2020;

\footnotetext{
${ }^{1}$ Rīga Stradiņš University, Institute for Occupational Safety and Environmental Health, Riga, Latvia, linda.matisane@rsu.lv, https://orcid.org/0000-0003-3978-6963

${ }^{2}$ Rīga Stradinš̌ University, Institute for Occupational Safety and Environmental Health, Riga, Latvia, linda.paegle@rsu.lv, https://orcid.org/0000-0002-2205-6676

${ }^{3}$ Rīga Stradiņš University, Institute for Occupational Safety and Environmental Health, Riga, Latvia, ivars.vanadzins@ @rsu.lv, https://orcid.org/0000-0002-5391-1583

${ }^{4}$ Rīga Stradiņš University, Institute for Occupational Safety and Environmental Health, Riga, Latvia, AsnateAnna.Linde@rsu.lv, https://orcid.org/0000-0001-7429-1216

${ }^{5}$ Vidzeme University of Applied Sciences, Valmiera, Latvia, Sarmite.Rozentale@ va.lv, https://orcid.org/0000-0002$0682-4196$

${ }^{6}$ Vidzeme University of Applied Sciences, Valmiera, Latvia, Ieva.Grintale@ va.lv, https://orcid.org/0000-0002-00430751

${ }^{7}$ Rēzekne Academy of Technologies, Rezekne, Latvia, Iveta.Mietule@ rta.lv, https://orcid.org/0000-0001-7662-9866

${ }^{8}$ Rēzekne Academy of Technologies, Rezekne, Latvia, Jelena.Lonska@rta.lv, https://orcid.org/0000-0002-8140-4810

${ }^{9}$ Rēzekne Academy of Technologies, Rezekne, Latvia, Lienite.Litavniece@ rta.lv, https://orcid.org/0000-0001-98597850

${ }^{10}$ Rēzekne Academy of Technologies, Rezekne, Latvia, Iluta.Arbidane@ rta.lv, https://orcid.org/0000-0002-9762-3874
} 
Oakman et al., 2020; Rodríguez-Nogueira et al., 2021). Telework during the COVID-19 pandemic had been a huge challenge for employers on how to fulfill their legal obligations - to ensure healthy and safe working conditions - due to external and rapidly changing conditions and lack of external advice (Belzunegui-Eraso \& Erro-Garcés, 2020).

The objective of this study was to identify the association between musculoskeletal pain reported by teleworkers and different preventive measures provided by the Latvian employers during the first emergency restrictions of the COVID-19 pandemic (in force between 12 March and 9 June, 2020). To reach the objective of this study, the following tasks were formulated: 1) to identify the percentage of teleworkers reporting pain longer than three days; 2) to analyze provided preventive measures for teleworkers, and 3) to analyze the association between the provided measures and self-reported pain. This paper provides evidence that easy and simple preventive measures taken by the employer to support their teleworkers can reduce the prevalence of musculoskeletal pain, which is important due to the fact that the COVID-19 pandemic is still ongoing and telework has become an essential part of working life of many workers and companies.

\section{Literature review}

According to the national legislation, telework is defined as the type of work that could be done in the employer's premises, but regularly is done outside these premises using information and communication technologies (The Republic of Latvia, 2002). Rather a similar definition can be found in literature, e.g., "telecom-muting is defined organization and/or execution of tasks performed away from the central offices or production facilities of organizations for a certain period in pre-established work schedules. To this end, information and communication technologies are used to establish communication between workers and to respond to the demands of the organization remotely" (de Macêdo et al., 2020). If the place in most cases during early stages of telework was home, then the development of telework lead to a very broad term - "working anytime anywhere" (Robelski et al., 2019). However, in the context of COVID-19, the approach of "working anytime anywhere" is not quite relevant as due to the requirements of social distancing and limiting the gathering of persons it was required to work remotely from home (Belzunegui-Eraso \& Erro-Garcés, 2020). Therefore, telework can be categorized as planned (e.g., as a voluntary choice of workers and agreed with the employer) and non-planned (e.g., forced due to COVID-19) (Belzunegui-Eraso \& Erro-Garcés, 2020).

If telework is a choice, it has its benefits like reduction of traffic problems and air pollution, higher productivity, less absenteeism, lower turnover rate, greater commitment, organizational performance (Greer \& Payne, 2014), increased autonomy, better work-life balance (Steidelmüller et al., 2020), improvement in emotional and motivational results (Biron \& van Veldhoven, 2016). However, it can also cause physical health problems similar to workers working in the employer's premises (Hedge et al., 2011). In addition, mental and personal isolation, the conflict between work and family life (de Macêdo et al., 2020), greater responsibilities and higher demands on self-management (Steidelmüller et al., 2020), increased stress levels (Eurofound and the International Labour Office, 2017; Melo \& de Abreu e Silva, 2017), longer working hours, including work also in leisure time (Eurofound and the International Labour Office, 2017) had also been observed in workers working from a distance. The benefits and side effects of telework are summarized in Table 1.

When discussing typical health issues related to working in office, the relationship between computer use and the development of musculoskeletal disorders has been well-documented as the most common problem (Eurostat, 2010; Harrington \& Walkers, 2004). Sore and tired eyes, pain in the neck (Hedge et al., 2011), pain in the back (Eurofound and the International Labour Office, 2017), sore wrists and tendon pain in the wrists and fingers (Eurofound and the International Labour Office, 2017; Hedge et al., 2011), lower physical activity (Kawada, 2020) have already been associated with telework. Forced telework during the COVID-19 pandemic has promoted the onset of musculoskeletal disorders, particularly low back pain and neck pain (Moretti et al., 2020). Among the main reasons improper workstation design, lack of appropriate equipment, incorrect monitor, mouse and keyboard placement, confinement and awkward postures for a prolonged time, use of kitchen chair, incorrect chair height, improper office lighting; and intense typing without resting periods, increased screen use and reduced physical activity should be mentioned (Harrington \& Walkers, 2004; Moretti et al., 2020; Majumdar et al., 2020; Siqueira et al., 2020). 


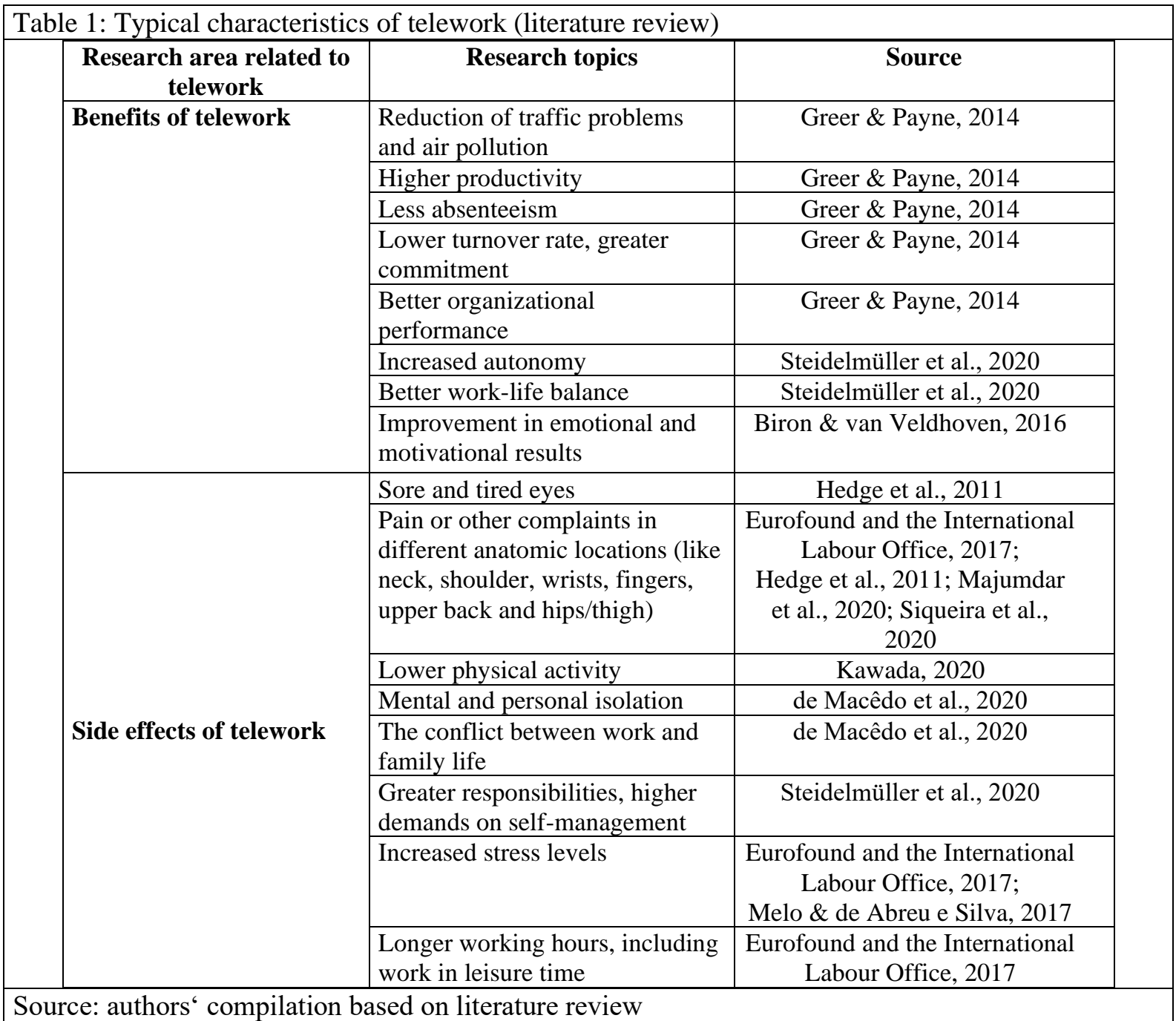

It has already been well described that different preventive measures and interventions provided by the employer to improve workplace ergonomics could reduce the prevalence of workers complaining about different health problems, including musculoskeletal disorders (Soares et al., 2020). When the worker is working in the premises of the company, many of these risk factors are managed through workplace risk assessment, and infrastructure as the company provides computers, other IT equipment, suitable office chairs and desks, arranges the computer workstations, invites occupational health and safety experts and ergonomists to improve working conditions (Chong et al., 2020; Harrington \& Walkers, 2004). In accordance with EU legislation, employers are responsible for performing workplace risk assessment that is also applicable to remote workplaces (Oakman et al., 2020). However, in the home office, teleworkers typically set up their own offices without assistance and training, sometimes even on coffee tables, ironing boards, kitchen tables or old desks (Harrington \& Walkers, 2004). In addition, in the COVID-19 situation, the transition to telework was massive and forced; and this forced form of mandatory telework is fundamentally distinct from voluntary telework (Belzunegui-Eraso \& ErroGarcés, 2020; Chong et al., 2020). For example, this has resulted in a lack of possibility to install equipment for workers to work remotely, companies were not allowed to send occupational health and safety experts to check working conditions in the teleworkers' homes and (Belzunegui-Eraso \& ErroGarcés, 2020).

In addition to the above mentioned, teleworkers report a lower level of awareness and knowledge about ergonomics and other occupational health and safety issues (von Bergen, 2008). It can be due to the fact that telework has been identified as a barrier to the implementation of participatory ergonomics programs designed to promote the health, safety, and wellbeing of workers (Schall \& Chen, 2021). Therefore, employers should provide targeted advice or resources for this group of workers covering such topics as ergonomics and criteria for structuring home offices, working in isolation, general 
occupational health and safety, and fire and electrical safety issues. That allows to change work habits and improve the physical home-based work environment (International Labour Organization, 2020b; Schall \& Chen, 2021; von Bergen, 008).

It should be pointed out that most of the described preventive measures do not require huge investments from the employers; these measures require creativity, will to support their workers and qualitative communication with their workers (e.g., permission to the worker to take the office chair form the employers' office to home office, provision of transportation for it, sending out free of charge informative materials or home office ergonomics, an invitation to submit photos of distance workplaces to be evaluated by companies occupational health and safety experts) (Rīga Stradiņš University; Vidzeme University of Applied Sciences; Rezekne Academy of Technologies, 2020). Lack of paying attention to ergonomics while working at home from the workers' side and showing no interest from employers' side has already been reported as a problem before the COVID-19 pandemic (Eurofound and the International Labour Office, 2017). The situation during the emergency state has worsened as telework was a forced challenge - the priority of employers was to survive during the COVID-19 crisis and to focus on main business aspects (e.g. paying salaries) (Eurofound and the International Labour Office, 2017; International Labour Organization, 2020a). Therefore, the occupational health and safety and well-being of workers were not a priority of many employers (Eurofound and the International Labour Office, 2017; International Labour Organization, 2020a).

\section{Data and methodology}

\section{Recruitment and data collection}

Web-survey as an online tool was used to quickly gather information from workers between 28 September and 27 October, 2020. It applied a non-probability sampling method. Survey participants were recruited using a snowball sampling method, social media advertisements, and direct emails to share the weblink of the questionnaire in Latvian. Each single person having access to the internet was able to fill in the questionnaire. The same recruiting principle was used during the Eurofound survey "Living, working and COVID-19" (Eurofound, 2020). At the beginning, written information on the purpose of the study was provided, therefore, participants, by voluntary proceeding to the questions, agreed to participate in the survey.

At the beginning of the web survey filter questions were applied to recruit only paid workers who were employed during the previous year. In total, 1823 persons responded to the questions, however only 1006 respondents answered all questions. 483 survey participants reported teleworking during the first emergency state, therefore, only those were selected for further analysis. The average age of respondents included in the analysis was $42.8+/-10.5$ ( $\min 22$, max 72 years), $15.3 \%$ were males and $84.7 \%$ females. Survey data were gathered and managed using REDCap (Research Electronic Data Capture) tool.

\section{Study variables}

The effect of ergonomics management by employers was analyzed using the following outcome variable of this study: self-reported pain lasting longer than three days during the emergency state. Two questions measured this outcome - at first, only those respondents who reported having pain (in lower back, neck, arms and hands, legs and feet, as well as headache) longer than three days were selected. These respondents were asked to answer the question "Did you have pain during the emergency state which was longer than three days?". Several answers were possible: "Yes, more often and / or more severe than before", "Yes, frequency and severity were the same as before", "Yes, but less often and / or less severe than before", "No, I did not have". Respondents who reported "I don't know / hard to say" were considered missing values and excluded from analysis (in total 46). Two groups of respondents were created for data analysis purposes: 1) teleworkers who reported having pain with any frequency and severity; 2) teleworkers who reported having no pain (this group included those who reported no pain during the emergency state and no pain in the previous year).

Different types of preventive measures provided by the employers were analyzed as independent factors in association with pain longer than three days. Respondents were asked to give feedback on the different statements (see Table 2). For all those statements, several answers for each preventive measure were possible: "It was necessary and was provided in all cases", "It was necessary, but was provided only in some cases", "It was necessary, but was not provided", "It was not necessary and was not provided" (in 
the article referred as "provided", "partly provided", "not provided", "not needed"). In all cases, respondents who selected the answer "I don't know / Hard to say" were excluded from the analysis.

For this article the following statements were used: "A computer and other IT equipment was provided to me", "I received advice how to arrange an ergonomic workstation", "My employer identified conditions where I am teleworking" and "My employer provided office table and office chair". When the authors of the survey constructed the questionnaire, the statement "My employer identified conditions where I am teleworking" was included in order to ask the respondents if the employer has provided workplace risk assessment for workplace located at home. Such wording for the statement was chosen to avoid the use of complicated/unclear legal terms.

\section{Statistical analysis}

Descriptive analyses (mean, standard deviation) and frequency analyses (percentages, distribution) were used to describe the data. The correlation between preventive measures and pain longer than three days was analyzed by using binomial logistic regression and calculated as odds ratios (ORs) with 95\% confidence intervals (CIs) in adjustment to gender and age. Gender and age as confounding variables were included in the regression models. Age was divided into the following groups: 18 - 24, 25 - 34, 35 - 44, $45-54,55-64$ and 65 - 74. The analysis was carried out using the IBM SPSS Statistics 26 (IBM Corporation, Armonk, New York, NY, USA) software.

\section{Results and Discussion}

In total, $35.7 \%$ of respondents $(n=156)$ reported pain longer than three days during the first emergency state, including $14.0 \%$ - reporting more often and/ or more severe pain than before, $16.9 \%$ - reporting pain with the same as before frequency and severity and $4.8 \%$ - having pain less often and / or less severe than before. In addition, $64.3 \%$ of respondents reported no pain. Although other studies report a significant proportion of teleworkers having pain or other complaints in different anatomic locations (like neck, shoulder, wrists, upper back and hips/thigh) during the early restriction period due to the COVID-19 pandemic, results of all of these studies are not fully compatible as different outcome variables have been used (pain longer than three days in our study versus discomfort in certain parts of the body) (Majumdar et al., 2020; Siqueira et al., 2020). These differences in study variables can explain the reason why other surveys on musculoskeletal disorders in teleworkers report that almost half of the respondents have experienced work-related pain (Eurofound and the International Labour Office, 2017), but the percentage of teleworkers reporting pain in our study was lower.

When looking at the preventive measures provided by the employer in our study, provision of a computer and other IT equipment was mentioned as the most frequent measure provided in all cases to $55.0 \%$ of respondents (Table 2). From the beginning, such results seem to be rather good, however, we should acknowledge that a computer is the most important tool for teleworkers and the lack of it results in the inability to perform a job and earn a salary. This is not just the question of being able to work, but also how effective is teleworking - qualitative teleworking requires the provision of appropriate equipment and high-quality technical support in conjunction with training in the necessary software and systems needed by an individual (Oakman et al., 2020).

Almost twenty one percent of respondents reported that his/her employer has fully provided identification of the working conditions, the other $7.5 \%$ of respondents mentioned partly provided this measure. According to EU legislation, employers have the responsibility of doing workplace assessment applicable to remote workplaces (Oakman et al., 2020). We can assume that the employer has fulfilled his/her legal obligations in less than $30 \%$ of all respondents - teleworkers.

Frequently, respondents mentioned that they have received advice on how to arrange an ergonomic workstation and that their employer has identified conditions where he/she was teleworking - such answer has been selected by $23.3 \%$ and $20.6 \%$ of respondents respectively. The least frequent measure reported by respondents was the provision of office tables and office chairs, which was mentioned by less than $8 \%$. In home office teleworkers typically set up their own offices without assistance and training on coffee tables or old desks; therefore, support in the means of advice and office furniture from the side of the employer is essential (Harrington \& Walkers, 2004).

The odds of self-reported pain longer than three days were increased in case of lack of all analyzed preventive measures (Table 3). In all cases except for lack of provision of a computer and other IT equipment, the association was strong for the unadjusted results and slightly weaker if gender and age 
were used for adjustment. The highest odds were identified for lack of provision of office table and office chair, followed by the lack of identification of teleworking conditions and advice on how to arrange an ergonomic workstation. Interest in working conditions, advice on home ergonomics, and taking an office table and chair from the employers' office to workers' home are cheap and easy measures to be implemented at the company level. The need for ergonomic training teleworkers has already been reported previously as this promotes ergonomic changes in the home offices based on the training and results in less frequent pain or discomfort while teleworking (Harrington \& Walkers, 2004).

Table 2: The distribution of the studied preventive measures provided by the employers for remote workplaces in the sample, $\mathrm{n}(\%)$

\begin{tabular}{|c|c|c|}
\hline $\begin{array}{l}\text { Statements describing preventive measures } \\
\text { provided by the employer }\end{array}$ & $\begin{array}{c}\text { Status of } \\
\text { preventive measure }\end{array}$ & $\mathrm{n},(\%)$ \\
\hline \multirow{4}{*}{$\begin{array}{l}\text { A computer and other IT equipment was provided } \\
\text { to me }\end{array}$} & Provided & $236(55.0 \%)$ \\
\hline & Partly provided & $53(12.3 \%)$ \\
\hline & Not provided & $66(15.3 \%)$ \\
\hline & Not needed & $75(17.4 \%)$ \\
\hline \multirow{4}{*}{$\begin{array}{l}\text { I received advice on how to arrange an ergonomic } \\
\text { workstation }\end{array}$} & Provided & $97(23.3 \%)$ \\
\hline & Partly provided & $35(8.4 \%)$ \\
\hline & Not provided & $86(20.6 \%)$ \\
\hline & Not needed & $199(47.7 \%)$ \\
\hline \multirow{4}{*}{$\begin{array}{l}\text { My employer identified conditions where I am } \\
\text { teleworking }\end{array}$} & Provided & $83(20.6 \%)$ \\
\hline & Partly provided & $30(7.5 \%)$ \\
\hline & Not provided & $126(31.3 \%)$ \\
\hline & Not needed & $163(40.6 \%)$ \\
\hline \multirow{4}{*}{$\begin{array}{l}\text { My employer provided an office table and office } \\
\text { chair }\end{array}$} & Provided & $32(7.7 \%)$ \\
\hline & Partly provided & $16(3.8 \%)$ \\
\hline & Not provided & $125(29.9 \%)$ \\
\hline & Not needed & $245(58.6 \%)$ \\
\hline
\end{tabular}

Table 3: The odds of self-reported pain longer than three days in association with measures provided by the employer

\begin{tabular}{|c|c|c|c|c|}
\hline & $\begin{array}{l}\text { Status of } \\
\text { preventive } \\
\text { measures }\end{array}$ & $\begin{array}{l}\text { Pain, } \\
\text { n (\%) }\end{array}$ & $\begin{array}{l}\text { Self-reported pain, } \\
\text { OR (CI 95\%) } \\
\text { Unadjusted }\end{array}$ & $\begin{array}{l}\text { Self-reported pain, } \\
\text { OR }(\text { CI } 95 \%)^{\mathrm{a}}, \\
\text { Adjusted for gender } \\
\text { and age }\end{array}$ \\
\hline \multicolumn{5}{|c|}{ A computer and other IT equipment was provided to me } \\
\hline & Not provided & $56(40.0 \%)$ & $\begin{array}{c}1.61 * * * \\
(1.03-2.52)\end{array}$ & $\begin{array}{c}1.50 \\
(0.95-2.37)\end{array}$ \\
\hline & Provided & $84(60.0 \%)$ & 1 & 1 \\
\hline \multicolumn{5}{|c|}{ My employer provided an office table and office chair } \\
\hline & Not provided & $66(94.3 \%)$ & $\begin{array}{c}6.16^{*} \\
(2.05-18.48)\end{array}$ & $\begin{array}{c}5.46 * * \\
(1.78-16.80)\end{array}$ \\
\hline & Provided & $4(5.7 \%)$ & 1 & 1 \\
\hline \multicolumn{5}{|c|}{ I received advice on how to arrange an ergonomic workstation } \\
\hline & Not provided & $57(69.5 \%)$ & $\begin{array}{c}2.57^{*} \\
(1.44-2.57) \\
\end{array}$ & $\begin{array}{c}2.37 * * \\
(1.32-4.25)\end{array}$ \\
\hline & Provided & $25(30.5 \%)$ & 1 & 1 \\
\hline \multicolumn{5}{|c|}{ My employer identified conditions where I am teleworking } \\
\hline & Not provided & $72(78.3 \%)$ & $\begin{array}{c}2.70^{*} \\
(1.49-4.89) \\
\end{array}$ & $\begin{array}{c}2.61 * * \\
(1.43-4.77) \\
\end{array}$ \\
\hline & Provided & $20(21.7 \%)$ & 1 & 1 \\
\hline
\end{tabular}

a. The reference category for the group with self-reported pain longer than three days is the group of respondents who did not have pain longer than three days.

$* \mathrm{p}<0.001, * * \mathrm{p}<0.01, * * * \mathrm{p}<0.05$

Source: results of the survey, authors' compilation 
Different results were obtained when analyzing the following statement „A computer and other IT equipment was provided to me". Although odds of self-reported pain longer than three days were increased in this case, the association was weaker, and the results were not significant if adjusted for age and gender. This might be explained by the fact that the ownership of the computer and other IT tools does not directly influence ergonomics of the workplace and thus also the prevalence of pain, but lack of such support from the side of the employer can influence the level of anxiety and stress which indirectly increases the prevalence of musculoskeletal pain (Moretti et al., 2020; Wahlström et al., 2004).

\section{Conclusions}

Our research provides data that teleworkers not receiving support from the employer on the arrangement of home offices have an increased risk of having pain for longer than three days. Particularly high risk was observed among workers who were not provided with an office worktable and office chair. Lower but still more than doubled risk, was observed among teleworkers who did not get advice on how to arrange an ergonomic workplace and who worked in the workplace where risk assessment was not performed. The employer's provision of a computer and other equipment can also reduce the prevalence of pain in teleworkers. Such results point out the need for awareness-raising activities for the employers, including sharing of good practice examples on easy and inexpensive preventive measures to improve home office ergonomics.

\section{Funding}

This research is funded by the Ministry of Education and Science, Republic of Latvia, project "Life with COVID-19: Evaluation of overcoming the coronavirus crisis in Latvia and recommendations for societal resilience in the future," project No. VPP-COVID-2020/1-0013

\section{Conflicts of Interest}

The authors declare no conflict of interest.

\section{Ethical approval}

Ethical approval for the study was granted by the Ethics Commission of Riga Stradin̄š University (protocol No. 6-1/08/16, 23.07.2020.) prior to the recruitment of any participants.

\section{Acknowledgments}

Authors thank Lāsma Akūlova for technical support.

\section{References}

Belzunegui-Eraso, A., \& Erro-Garcés, A. (2020). Teleworking in the context of the Covid-19 crisis. Sustainability (Switzerland), 12(9). https://doi.org/10.3390/su12093662

Biron, M., \& van Veldhoven, M. (2016). When control becomes a liability rather than an asset: Comparing home and office days among part-time teleworkers. Journal of Organizational Behavior, 37(8). https://doi.org/10.1002/job.2106

Chong, S. H., Huang, Y., \& Daisy Chang, C. H. (2020). Supporting Interdependent Telework Employees: A ModeratedMediation Model Linking Daily COVID-19 Task Setbacks to Next-Day Work Withdrawal. Journal of Applied Psychology, 105(12), 1408-1422. https://doi.org/10.1037/ap10000843

de Macêdo, T. A. M., Cabral, E. L. D. S., Silva Castro, W. R., de Souza Junior, C. C., da Costa Junior, J. F., Pedrosa, F. M., da Silva, A. B., de Medeiros, V. R. F., de Souza, R. P., Cabral, M. A. L., \& Másculo, F. S. (2020). Ergonomics and telework: A systematic review. Work, 66(4), 777-788. https://doi.org/10.3233/WOR-203224

Eurofound. (2020). Living, working and COVID-19. In Publications Office of the European Union. Retrieved February, 22, 2021, from https://www.eurofound.europa.eu/sites/default/files/ef_publication/field_ef_document/ef20059en.pdf

Eurofound and the International Labour Office. (2017). Working anytime, anywhere: The effects on the world of work. Retrieved February, 22, 2021, from https://www.ilo.org/wcmsp5/groups/public/---dgreports/---dcomm/--publ/documents/publication/wcms_544138.pdf

Eurostat. (2010). Health and safety at work in Europe (1999-2007) - A statistical portrait. In Publications Office of the European Union. Retrieved February, 22, 2021, from https://ec.europa.eu/eurostat/documents/3217494/5718905/KS-31-09290-EN.PDF.pdf/88eef9f7-c229-40de-b1cd-43126bc4a946?t=1414775047000

Greer, T. W., \& Payne, S. C. (2014). Overcoming telework challenges: Outcomes of successful telework strategies. Psychologist-Manager Journal, 17(2). https://doi.org/10.1037/mgr0000014

Harrington, S. S., \& Walkers, B. L. (2004). The effects of ergonomics training on the knowledge, attitudes, and practices of teleworkers. Journal of Safety Research, 35(1). https://doi.org/10.1016/j.jsr.2003.07.002

Hedge, A., James, T., \& Pavlovic-Veselinovic, S. (2011). Ergonomics concerns and the impact of healthcare information technology. International Journal of Industrial Ergonomics, 41(4). https://doi.org/10.1016/j.ergon.2011.02.002 
International Labour Organization. (2020). The impact of the COVID-19 pandemic on jobs and incomes in G20 economies. Retrieved February, 22, 2021, from https://www.ilo.org/wcmsp5/groups/public/---dgreports/--cabinet/documents/publication/wcms_756331.pdf

International Labour Organization. (2020). A Practical Guide on Teleworking during the COVID-19 pandemic and beyond. Retrieved September, 12, 2021, from: https://www.ilo.org/wcmsp5/groups/public/---ed_protect/---protrav/--travail/documents/instructionalmaterial/wcms_751232.pdf

Kawada, T. (2020). Telework and Work-Related Well-Being. Journal of Occupational and Environmental Medicine, 62(12). https://doi.org/10.1097/JOM.0000000000002058

Majumdar, P., Biswas, A., \& Sahu, S. (2020). COVID-19 pandemic and lockdown: cause of sleep disruption, depression, somatic pain, and increased screen exposure of office workers and students of India. Chronobiology International, 37(8), 1191-1200. https://doi.org/10.1080/07420528.2020.1786107

Melo, P. C., \& de Abreu e Silva, J. (2017). Home telework and household commuting patterns in Great Britain. Transportation Research Part A: Policy and Practice, 103, 1-24. https://doi.org/10.1016/j.tra.2017.05.011

Moretti, A., Menna, F., Aulicino, M., Paoletta, M., Liguori, S., \& Iolascon, G. (2020). Characterization of home working population during covid-19 emergency: A cross-sectional analysis. International Journal of Environmental Research and Public Health, 17(17). https://doi.org/10.3390/ijerph17176284

Oakman, J., Kinsman, N., Stuckey, R., Graham, M., \& Weale, V. (2020). A rapid review of mental and physical health effects of working at home: how do we optimise health? BMC Public Health, 20(1), 31. https://doi.org/10.1186/s12889-02009875-z

Rīga Stradiņš University; Vidzeme University of Applied Sciences; Rezekne Academy of Technologies. (2020). Additional project results No. 31. Retrieved February, 22, 2021, from http://stradavesels.lv/Uploads/2021/01/05/31_zinojums_c.pdf

Robelski, S., Keller, H., Harth, V., \& Mache, S. (2019). Coworking spaces: The better home office? A psychosocial and health-related perspective on an emerging work environment. International Journal of Environmental Research and Public Health, 16(13). https://doi.org/10.3390/ijerph16132379

Rodríguez-Nogueira, Ó., Leirós-Rodríguez, R., Benítez-Andrades, J. A., Álvarez-álvarez, M. J., Marqués-Sánchez, P., \& Pinto-Carral, A. (2021). Musculoskeletal pain and teleworking in times of the COVID-19: Analysis of the impact on the workers at two Spanish universities. International Journal of Environmental Research and Public Health, 18(1). https://doi.org/10.3390/ijerph18010031

Schall, M.C.; Chen, P. (2021). Evidence-Based Strategies for Improving Occupational Safety and Health Among Teleworkers During and After the Coronavirus Pandemic. Human Factors, doi:10.1177/0018720820984583.

Siqueira, L. T. D., Santos, A. P. dos, Silva, R. L. F., Moreira, P. A. M., Vitor, J. da S., \& Ribeiro, V. V. (2020). Vocal SelfPerception of Home Office Workers During the COVID-19 Pandemic. Journal of Voice.

https://doi.org/10.1016/j.jvoice.2020.10.016

Soares, C. O., Pereira, B. F., Pereira Gomes, M. V., Marcondes, L. P., de Campos Gomes, F., \& de Melo-Neto, J. S. (2020). Preventive factors against work-related musculoskeletal disorders: narrative review. Revista brasileira de medicina do trabalho : publicacao oficial da Associacao Nacional de Medicina do Trabalho-ANAMT, 17(3), 415-430. https://doi.org/10.5327/Z1679443520190360

Steidelmüller, C., Meyer, S. C., \& Müller, G. (2020). Home-Based Telework and Presenteeism Across Europe. Journal of Occupational and Environmental Medicine, 62(12), 998-1005. https://doi.org/10.1097/JOM.0000000000001992

The Republic of Latvia. (2002). Labour Protection Law. Retrieved February, 22, 2021, from https://likumi.lv/ta/en/en/id/26020

von Bergen, C.W. (2008). Safety and Workers' Compensation Considerations in Telework. In Proceedings of the Regional Business Review. Booth College of Business and Professional Studies; pp. 131-153.

Wahlström, J., Hagberg, M., Toomingas, A., \& Wigaeus Tornqvist, E. (2004). Perceived muscular tension, job strain, physical exposure, and associations with neck pain among VDU users; a prospective cohort study. Occupational and Environmental Medicine, 61(6), 523-528. https://doi.org/10.1136/oem.2003.009563 